\title{
Dampak Anggaran, Kesulitan Geografis, dan Rumah Tangga Desa terhadap Status Desa di Provinsi Riau
}

\author{
The Impact of Budget, Geographic Difficulty, and Village Households \\ on Village Status in Riau Province
}

\author{
Bakti Kharisma $^{{ }^{*}}$, Werry Darta Taifur $^{2} \&$ Fajri Muharja $^{2}$ \\ ${ }^{1}$ Magister Ekonomi, Fakultas Ekonomi, Universitas Andalas, Limau Manis Padang, Sumatera Barat 25163, \\ Indonesia; ${ }^{2}$ Fakultas Ekonomi Universitas Andalas Padang, Limau Manis Padang, Sumatera Barat 25163, \\ Indonesia; *Penulis korespondensi. e-mail: baktikharisma@gmail.com
}

(Diterima: 31 Maret 2021; Disetujui: 20 Mei 2021)

\begin{abstract}
Enactment of the Village Law brings enthusiasm to the rural development paradigm. One of the main outputs of the government planning document is the increase of priority development in rural areas and villages. This is implemented by increasing the source of village income budget through the village fund program. This study aims to analyze the impact of village budgets and geographic difficulties, and village households on village status in Riau Province. Multiple linear regression model was used to analyze the impact of Village Fund allocation, Village Fund, Geographical Difficulty Index, and number of households in 2018 on the achievements of the Developing Village Index in 2019. Research results show that Village Fund allocation budget and the number of households have positive impacts on the Developing Village Index (Indeks Desa Membangun). in Riau Province. Meanwhile, increase in Village Fund budget and Geographical Difficulty Index have negative impacts on the Developing Village Index in Riau Province.
\end{abstract}

Keywords: budget impact, Geographic Difficulty Index, Riau province, village fund, village status

\begin{abstract}
ABSTRAK
Pemberlakuan Undang-Undang Desa membawa semangat untuk mengubah paradigma pembangunan pedesaan. Salah satu output utama dokumen perencanaan pemerintah adalah peningkatan pembangunan prioritas pada daerah pinggiran dan desa. Hal ini diwujudkan dengan bertambahnya sumber anggaran pendapatan desa dengan adanya program dana desa. Penelitian ini bertujuan menganalisis dampak anggaran pendapatan desa, kesulitan geografis, dan rumah tangga desa terhadap status desa di Provinsi Riau. Model regresi linear berganda digunakan untuk menganalisis dampak Alokasi Dana Desa, Dana Desa, Indeks Kesulitan Geografis, dan jumlah rumah tangga tahun 2018 terhadap capaian Indeks Desa Membangun tahun 2019. Penelitian ini menghasilkan kesimpulan bahwa anggaran Alokasi Dana Desa dan jumlah rumah tangga berdampak positif terhadap kenaikan Indeks Desa Membangun di Provinsi Riau. Di sisi lain, kenaikan anggaran Dana Desa dan Indeks Kesulitan Geografis berdampak negatif terhadap Indeks Desa Membangun di Provinsi Riau.
\end{abstract}

Kata kunci: dampak anggaran, dana desa, Indeks Kesulitan Geografis, provinsi Riau, status desa 


\section{PENDAHULUAN}

Semangat Undang-Undang Desa bertujuan membangun desa menuju kemandirian. Berbagai program dan kegiatan dari pemerintah pusat dan daerah telah diimplikasikan untuk memajukan desa, meningkatkan kesejahteraan dan mengurangi ketimpangan antara perkotaan dan perdesaan. Bahkan sejak tahun 2015 pemerintah desa telah mendapatkan alokasi dana transfer dari pemerintah pusat yang langsung ke desa dengan kebijakan dana desa. Implementasi dari dana pembangunan perdesaan memberikan peluang baru yang bisa meningkatkan lapangan kerja dan mengembangkan kegiatan ekonomi baru melalui program-program pemberdayaan masyarakat pedesaan yang berorientasi memajukan dan perubahan kesejahteraan masyarakat desa kearah yang lebih baik.

Pendapatan terbesar yang diterima oleh desa di Provinsi Riau pada tahun 2018 secara rata-rata bersumber dari Alokasi Dana Desa dan Dana Desa. Alokasi Dana Desa merupakan bagian dana perimbangan yang diterima kabupaten/kota minimal sebesar 10 Persen dalam Anggaran Pendapatan dan Belanja Daerah (APBD) setelah dikurangi dana alokasi khusus. Sedangkan Dana Desa adalah dana transfer pemerintah pusat yang bersumber dari Anggaran Pendapatan dan Belanja Negara (APBN) untuk desa dengan mekanisme penyaluran melalui APBD kabupaten/kota yang penggunaannya bertujuan untuk belanja bidang pemerintahan, pembangunan, pembinaan kemasyarakatan, dan pemberdayaan masyarakat.

Tahun 2018 merupakan tahun ke empat dilaksanakannya kebijakan Dana Desa. Selama empat tahun alokasi anggaran Dana Desa telah meningkat dari semula Rp 20 triliun pada tahun 2015 menjadi Rp 60 triliun di tahun 2018. Ratarata Dana Desa yang diterima oleh desa di Provinsi Riau pada tahun 2018 berjumlah Rp 848,776,382.00 sedangkan rata-rata Alokasi Dana Desa berjumlah Rp 848,776,382.00. Dalam pelaksanaannya pemerintah desa diminta melakukan pengelolaan anggaran dengan bijak, sesuai dengan prioritas kebutuhan dengan sasaran meningkatkan keberhasilan pembangunan desa dan kemandirian desa.

Gambaran negara lain dapat dijadikan acuan untuk mencapai keberhasilan pembangunan desa (Kuncoro, 2019). Sebagai contoh Australia mempromosikan ketahanan, daya saing dan keberlanjutan bisnis dan industri di desa melalui pengembangan kebijakan dan program terintegrasi dalam area pembangunan kapasitas, keterampilan yang mendukung keluarga pedesaan berkategori miskin. Norwegia memiliki kebijakan publik yang mengedepankan pertumbuhan infrastruktur dan pusat pertumbuhan dalam membangun desa. Kebijakan pembangunan desa di Jepang mengedepankan pembangunan pertanian untuk mengurangi disparitas ekonomi antar wilayah. Terakhir di India kebijakan pengembangan desa dilakukan dengan cara memperkuat struktur masyarakat pedesaan pada pemanfaatan sumber daya alam dengan membangun infrastruktur kokoh.

Indeks Desa Membangun merupakan salah satu alat ukur tingkat pembangunan desa (Yulitasari \& Tyas, 2020). Indeks Desa Membangun didesain untuk memperkuat upaya mencapai tujuan pembangunan desa dan bermanfaat dalam menganalisis status perkembangan masing-masing desa yang berkaitan erat dengan karakteristik serta dikembangkan sebagai instrumen pencapaian target rencana pembangunan pemerintah (Hanibal, 2015). Indeks Desa Membangun membagi lima kategori status desa yakni desa sangat tertinggal, desa tertinggal, desa berkembang, desa maju dan desa mandiri. Penentuan status diperoleh atas dasar hasil pengukuran tiga kelompok variabel yakni sosial, ekonomi dan lingkungan. Status desa Provinsi Riau berdasarkan Indeks Desa Membangun tahun 2019 terdiri dari 45 desa sangat tertinggal, 422 desa tertinggal, 961 desa berkembang, 163 desa maju, dan 10 desa mandiri. Keberhasilan pembangunan wilayah tidak terlepas dari ketersediaan infrastruktur Oleh karenanya karakteristik desa menjadi poin penting dalam penyerapan anggaran desa 
menuju kemandirian. Ketersediaan pelayanan dasar, akses pendidikan, kesehatan dan sanitasi merupakan hal yang paling mendasar yang dibutuhkan oleh desa. Desa dengan ketersediaan pelayanan dasar yang rendah tentu berbeda kebutuhannya dengan desa dengan pelayanan dasar yang memadai. Salah satu instrumen mengukur kondisi aspek pelayanan dasar di desa adalah Indeks Kesulitan Geografis. Indeks Kesulitan Geografis merupakan instrumen pengukuran kesulitan geografis suatu desa berdasarkan hasil integrasi nilai ketersediaan pelayanan dasar, kondisi infrastruktur, transportasi, dan komunikasi. Indeks Kesulitan Geografis memiliki nilai skor 0 sampai dengan 100 dimana skor yang mendekati angka 100 maka tingkat kesulitan geografisnya semakin tinggi. Sebaliknya, desa dengan skor yang mendekati angka 0 maka tingkat kesulitan geografisnya semakin rendah dengan lebih tersedianya pelayanan dasar, infrastruktur yang baik dan tersedianya sarana transportasi.

Penelitian tentang pemanfaatan Alokasi Dana Desa dan Dana Desa kondisi geografis dan rumah tangga dengan status desa telah banyak dilakukan. (Lewis, 2015) mengemukakan bahwa peningkatan kapasitas fiskal desa melalui Dana Desa dan Alokasi Dana Desa akan meningkatkan peluang pembangunan desa yang lebih baik, sedangkan peningkatan satu persen populasi desa, Indeks Kesulitan Geografis dan jumlah penduduk miskin akan berdampak kepada potensi pembangunan desa yang menurun. (Menkhof \& Rungrusixrivorn, 2011) menyimpulkan dana desa berkontribusi positif menaikkan angka kesejahteraan rumah tangga desa di Thailand. (Pratomo, 2018) menerangkan bahwa Dana Desa efektif dalam meningkatkan produktivitas rumah tangga desa dengan kegiatan padat karya untuk mendukung pertumbuhan ekonomi. (Riyanto, 2017) menghasilkan kesimpulan penggunaan dana desa dengan status desa sangat tertinggal dan desa tertinggal dititikberatkan pada penyelenggaraan pemerintah desa dan pembangunan infrastruktur. Hasilnya meningkatkan status desa tahun 2016 dari semula tertinggal menjadi berkembang. Pada penelitian ini tidak menjadikan Alokasi Dana Desa sebagai variable. (Oktaviana \& Bachruddin, 2017) menghasilkan kesimpulan rendahnya nilai Indeks Desa Membangun di wilayah Provinsi Banten memerlukan intervensi dari pemerintah provinsi untuk meningkatkan capaian indeks ketahanan ekonomi dan ketahanan lingkungan. Penelitian ini tidak menjadikan Alokasi Dana Desa dan Dana Desa sebagai objek penelitian. Muhtarom et al. (2018) menghasilkan kesimpulan pemberdayaan masyarakat desa di Gadingrejo mampu memberikan kontribusi positif dalam mendorong ketahanan sosial desa. (Lalira et al., 2018) menyimpulkan bahwa Alokasi Dana Desa dan Dana Desa tidak memiliki hubungan terhadap tingkat kemiskinan. Penelitian dengan hasil berbeda dilakukan oleh (Sunu \& Utama, 2019) yang menyimpulkan Dana Desa berpengaruh negatif pada tingkat kemiskinan tetapi berdampak positif pada kesejahteraan masyarakat. (Gani et al., 2020) menghasilkan kesimpulan pemanfaatan Dana Desa memiliki pengaruh yang positif terhadap variabel Indeks Desa Membangun dengan status desa yang semakin meningkat. (Yulitasari \& Tyas, 2020) menyimpulkan bahwa perubahan anggaran Dana Desa tidak memiliki dampak yang kuat dalam perubahan status desa di Jawa Tengah. (Joetarto et al., 2020) dalam penelitiannya menghasilkan kesimpulan intervensi Dana Desa berpengaruh positif terhadap peningkatan pengeluaran perkapita penduduk per desa.

Beberapa penelitian lain menghasilkan kesimpulan partisipasi masyarakat yang tinggi dalam setiap kegiatan perencanaan, pelaksanaan, monitoring dan evaluasi menjadi kunci terlaksananya program dana desa dengan baik dan sesuai aturan (Putra et al., 2013), (Aziz, 2016), (Daraba, 2017) dan (Arifa, 2019). Selanjutnya Dana Desa juga memberikan kontribusi dalam membuka lapangan kerja pada kegiatan padat karya untuk meningkatkan kesejahteraan masyarakat. (Atmojo et al., 2017), (Tangkumahat et al., 2017), (Sofianto, 2017), (Karmawan et al., 2020). 
Anggaran Alokasi Dana Desa dan Dana Desa yang disalurkan kepada desa di Provinsi Riau pada tahun 2018 berkisar Rp1.6 miliar Besarnya alokasi anggaran tersebut ternyata belum mampu meningkatkan capaian meningkatkan kemandirian desa. Capaian Indeks Desa Membangun tahun 2019 masih menyisakan 45 desa sangat tertinggal dan 422 desa berstatus tertinggal dan hanya sebanyak 10 desa dengan status desa mandiri.

\section{METODOLOGI}

Metode penelitian ini adalah penelitian kuantitatif. Sumber data yang digunakan adalah data sekunder yang terdiri dari data anggaran Alokasi Dana Desa dan anggaran Dana Desa tahun 2018 yang diperoleh dari aplikasi siskeudes Dinas Pemberdayaan Masyarakat Desa Kabupaten di Provinsi Riau, Indeks Kesulitan Geografis tahun 2016 yang bersumber dari Badan Pusat Statistik, Kementerian Keuangan dan data jumlah rumah tangga diperoleh dari data Podes Tahun 2018 serta nilai Indeks Desa Membangun per desa di Provinsi Riau tahun 2019 yang bersumber dari Kementerian Desa, Pembangunan Daerah tertinggal dan Transmigrasi

Unit analisis dalam penelitian ini adalah desa dengan populasi seluruh desa di Provinsi Riau yang berjumlah sebanyak 1,591 desa. Selanjutnya dilakukan pengumpulan data sampel desa yang ada di Provinsi Riau.

Pengumpulan data dilakukan dengan mengirimkan permintaan data pada masingmasing kabupaten di Provinsi Riau untuk perolehan data Alokasi Dana Desa dan Dana Desa tahun anggaran 2018 dengan periode pengumpulan data selama kurun waktu Agustus sampai dengan Desember 2020. Hasil perolehan data terkait data anggaran desa berbasis aplikasi sistem keuangan desa (Siskeudes) adalah sebanyak 1,032 desa yang tersebar di 8 Kabupaten dari 10 kabupaten sedangkan data anggaran yang tidak dapat diperoleh adalah sebanyak 559 Desa.

Teknik pemilihan sampel jenuh tidak dapat dilakukan karena sebanyak 35 persen data tidak tersedia dan sebaran data tidak tersedia pada 2 kabupaten yakni Kabupaten Kampar dan Kuantan singingi, sehingga peneliti menggunakan metode non probability sampling dengan teknik accidental sampling. Teknik accidental sampling adalah Teknik pengumpulan data yang tidak terduga, yaitu, mengumpulkan setiap orang yang cocok sebagai sumber data, dapat dijadikan sampel (Sugiyono, 2017). Data sebanyak 1,032 desa melalui accidental sampling dijadikan sampel untuk mewakili keseluruhan populasi desa di Provinsi Riau.

Pendekatan penelitian ini melalui teori produksi. Fungsi produksi didefinisikan sebagai hubungan teknis antara input dengan output, hubungan ini menunjukkan output sebagai fungsi dari input (Soekartawi, 1990). Fungsi produksi dalam beberapa pembahasan ekonomi produksi banyak diminati dan dianggap penting karena:

1. Fungsi produksi dapat menjelaskan hubungan antara faktor produksi dengan produksi itu sendiri secara langsung dan hubungan tersebut dapat lebih mudah dimengerti.

2. Fungsi produksi mampu mengetahui hubungan antara variabel yang dijelaskan (Q), dengan variabel yang menjelaskan (X) serta sekaligus mampu mengetahui hubungan antar variabel penjelasnya (antara $X$ dengan $X$ yang lain). Secara matematis sederhana, fungsi produksi dapat ditulis sebagai berikut :

$$
\begin{aligned}
& \text { Output }=f(\text { input }) \ldots \\
& \mathrm{Q}=\mathrm{f}(\mathrm{X} 1, \mathrm{X} 2, \mathrm{X} 3, \ldots, \mathrm{Xi}), \\
& \text { dimana: } \\
& \mathrm{Q}=\text { output } \\
& \mathrm{Xi}=\text { input yang digunakan dalam } \\
& \text { proses produksi; } \mathrm{i}=1,2,3, \ldots, \mathrm{n} .
\end{aligned}
$$

Input yang digunakan dalam proses produksi antara lain adalah modal, tenaga kerja, dummy, dan lain-lain. Dalam ilmu ekonomi, output dinotasikan dengan $\mathrm{Q}$ sedangkan input (faktor produksi) yang digunakan biasanya (untuk penyederhanaan) terdiri dari input 
kapital (K) dan tenaga kerja (L). Dengan demikian : $\mathrm{Q}=f(\mathrm{~K}, \mathrm{~L})$.

Dengan mengasumsikan $\mathrm{Y}$ sebagai capaian hasil produksi yang dinyatakan dalam Indeks Desa Membangun, modal diasumsikan sebagai anggaran Alokasi Dana Desa dan Dana Desa, Indeks Kesulitan Geografis sebagai modal keadaan alam sebagai pembeda kemampuan produksi masing-masing desa serta Tenaga kerja didasarkan pada Jumlah Rumah Tangga Desa maka variabel yang digunakan dalam penelitian ini menggunakan capaian nilai Indeks Desa Membangun Tahun 2019 sebagai variabel terikat yang dilambangkan dengan $\mathrm{Y}$, sedangkan variabel bebas atau independen menggunakan anggaran Alokasi Dana Desa sebagai X1, anggaran Dana Desa sebagai X2, Indeks Kesulitan Geografis sebagai X3 Dan Jumlah Rumah Tangga sebagai $\mathrm{X} 4$.

Model analisis regresi linear berganda yang dipergunakan secara matematis dapat diuraikan sebagai berikut:

$$
\mathrm{Y}=\beta 0+\beta 1 \mathrm{X} 1_{\mathrm{i}}+\beta 2 \mathrm{X} 2_{\mathrm{i}}+\beta 3 \mathrm{X} 3_{\mathrm{i}}+\beta 4 \mathrm{X} 4_{\mathrm{i}}+\mathrm{e}_{\mathrm{i}}
$$

Dengan

$\mathrm{Y}=$ nilai Indeks Desa Membangun

$\mathrm{B} 1, . . \beta 4=$ konstanta variabel independen

$\mathrm{X} 1_{\mathrm{i}} \quad=$ Alokasi Dana Desa desa $i$

$\mathrm{X} 2_{\mathrm{i}} \quad=$ Anggaran Dana Desa desa $i$

$\mathrm{X} 3_{\mathrm{i}} \quad=$ Indeks Kesulitan Geografis desa

$\mathrm{X} 4_{\mathrm{i}} \quad=$ jumlah rumah tangga desa $i$

$\mathrm{e}_{\mathrm{i}} \quad=$ error desa $i$

Hipotesis dalam penelitian ini adalah

$\mathrm{H}_{0}$ : tidak ada pengaruh signifikan Alokasi Dana Desa, Dana Desa, Indeks Kesulitan Geografis dan Jumlah Rumah Tangga terhadap nilai Indeks Desa Membangun

$\mathrm{H}_{1}$ : Terdapat pengaruh signifikan Alokasi Dana Desa, Dana Desa, Indeks Kesulitan Geografis dan Jumlah Rumah Tangga terhadap nilai Indeks Desa Membangun.

\section{HASIL DAN PEMBAHASAN}

\section{Indeks Desa Membangun Provinsi Riau}

Berdasarkan Peraturan Menteri Desa, Pembangunan Daerah Tertinggal dan Transmigrasi Nomor 2 Tahun 2016 Indeks Desa Membangun merupakan salah satu instrumen untuk mengukur perkembangan status kemandirian desa dengan menganalisis dan menggabungkan semua skor indikator dipilih berdasarkan konsep kebijakan pembangunan yang telah ditetapkan. Oleh karena itu, hasil analisis Indeks Desa Membangun dapat dijadikan bahan kebijakan perencanaan dalam menentukan status kemandirian desa. Pondasi penilaian Indeks Desa Membangun didasarkan atas 3 dimensi yakni, ketahanan sosial, ketahanan ekonomi dan ketahanan lingkungan. Masing-masing dimensi tersebut merupakan kumpulan variabel dengan jumlah 22 variabel yang diperluas dengan 52 indikator operasional.

Pemenuhan indikator Indeks Desa Membangun tidak semuanya dapat dilaksanakan oleh pemerintah desa. Karena desa hanya memiliki kewenangan sebanyak 33 Indikator dari total 54 indikator yang menjadi objek penilaian. Sedangkan pemerintah kabupaten memiliki kewenangan pada 42 indikator, pemerintah provinsi 19 Indikator dan Pemerintah pusat sebanyak 14 indikator. 9 indikator sisanya merupakan indikator murni yang dibentuk berdasarkan kondisi alami dan sosial kultural masyarakat.

Output hasil penilaian Indeks Desa Membangun akan mengkategorikan desa dalam 5 (lima) status desa seperti tabel dibawah ini:

Tabel 1. Klasifikasi status desa berdasarkan Indeks Desa Membangun

\begin{tabular}{ll}
\hline \multicolumn{1}{c}{ Status Desa } & \multicolumn{1}{c}{ Nilai Indeks } \\
\hline Sangat tertinggal & nilai IDM $<0.491$ \\
Tertinggal & nilai $0.491<$ IDM $<0.599$ \\
Berkembang & nilai $0.599<$ IDM $<0.707$ \\
Maju & nilai $0.707<$ IDM $<0.815$ \\
Mandiri & nilai IDM $>0.815$ \\
\hline Sumber: Peraturan Menteri Desa PDT dan Transmigrasi \\
\multicolumn{2}{c}{ Nomor 2 Tahun 2016 }
\end{tabular}


Desa sangat tertinggal merupakan desa yang rentan terhadap bencana alam, guncangan ekonomi dan konflik sosial membuat mereka tidak mampu mengelola potensi sumber daya sosial, ekonomi dan ekologi serta menderita berbagai bentuk kemiskinan. Desa sangat tertinggal adalah desa dengan nilai indeks kurang dari $(\leq)$ 0.491. Desa tertinggal merupakan Desa dengan potensi sumberdaya sosial, ekonomi dan ekologi belum atau kurang dikelola dengan baik dalam upaya peningkatan kesejahteraan masyarakat, kualitas hidup dan berbagai bentuk kemiskinan desa tertinggal memiliki indeks diantara 0.491 sampai dengan 0.599. Desa berkembang merupakan desa yang berpotensi menjadi desa maju yang memiliki potensi sumberdaya sosial, ekonomi dan lingkungan, namun belum dikelola secara optimal dalam rangka meningkatkan kesejahteraan, kehidupan dan kualitas manusia serta mengentaskan kemiskinan. Desa berkembang memiliki nilai indeks pada rentang 0.599 sampai 0.707 .

Tabel 2. Indeks Desa Membangun per Kabupaten di Provinsi Riau Tahun 2019

\begin{tabular}{|c|c|c|c|c|c|c|c|c|}
\hline \multirow{2}{*}{ No } & \multirow{2}{*}{$\begin{array}{c}\text { Nama } \\
\text { Kabupaten }\end{array}$} & \multirow{2}{*}{$\begin{array}{c}\text { Jumlah } \\
\text { Desa }\end{array}$} & \multirow{2}{*}{$\begin{array}{c}\text { Nilai } \\
\text { Rata- } \\
\text { rata }\end{array}$} & \multicolumn{5}{|c|}{ Status Desa } \\
\hline & & & & $\begin{array}{c}\text { Sangat } \\
\text { Tertinggal }\end{array}$ & Tertinggal & Berkembang & Maju & Mandiri \\
\hline 1 & Kep. Meranti & 96 & 0.6004 & 6 & 36 & 51 & 3 & 0 \\
\hline 2 & Kuantan Sengingi & 218 & 0.6058 & 4 & 97 & 107 & 10 & 0 \\
\hline 3 & Siak & 122 & 0.6695 & 0 & 4 & 94 & 21 & 3 \\
\hline 4 & Rokan Hilir & 159 & 0.6340 & 2 & 33 & 107 & 17 & 0 \\
\hline 5 & Rokan Hulu & 139 & 0.6543 & 2 & 17 & 101 & 18 & 1 \\
\hline 6 & Pelalawan & 104 & 0.6413 & 1 & 20 & 68 & 11 & 4 \\
\hline 7 & Indragiri Hilir & 197 & 0.5822 & 11 & 116 & 59 & 11 & 0 \\
\hline 8 & Bengkalis & 136 & 0.6613 & 0 & 10 & 100 & 25 & 1 \\
\hline 9 & Indragiri Hulu & 178 & 0.6337 & 2 & 37 & 116 & 23 & 0 \\
\hline \multirow[t]{2}{*}{10} & Kampar & 242 & 0.6280 & 17 & 52 & 148 & 24 & 1 \\
\hline & Provinsi Riau & 1,591 & 0.6264 & 45 & 422 & 951 & 163 & 10 \\
\hline
\end{tabular}

Sumber: Keputusan Menteri Desa PDT dan Transmigrasi Nomor 201 Tahun 2019

Desa maju merupakan desa yang mampu memanfaatkan tiga potensi yang dimiliki untuk membangun kesejahteraan, kualitas hidup dan mengentaskan kemiskinan masyarakat desa. Desa maju memiliki nilai indeks pada rentang 0.707 sampai dengan 0.815. Desa mandiri merupakan status desa yang memiliki kekuatan segala potensi yang dimiliki untuk membangun desa menuju kemandirian kesejahteraan kualitas hidup dari aspek sosial,ekonomi dan lingkungan yang sustainable. Desa mandiri memiliki nilai indeks diatas 0.815 .

Status desa Provinsi Riau berdasarkan Indeks Desa Membangun tahun 2019 memiliki rata-rata 0.6264 terdiri dari $45(2.8 \%)$ desa sangat tertinggal, $422(26.5 \%)$ desa tertinggal, $961(60.4 \%)$ desa berkembang, $163(10.2 \%)$ desa maju dan $10(0.6 \%)$ desa mandiri dengan rincian sesuai Tabel 3.

Berdasarkan Tabel 2 di atas, kabupaten dengan nilai rata-rata Indeks Desa Membangun tertinggi adalah Kabupaten Siak dengan nilai ratarata 0.6695 dan kabupaten terendah adalah Kabupaten Indragiri Hilir dengan nilai 0.5822 . Sembilan dari sepuluh kabupaten memiliki nilai rata-rata Indeks Desa Membangun terkategori desa berkembang didukung dengan desa dengan status desa berkembang yang mendominasi dibandingkan status desa lainnya dan hanya 1 kabupaten dengan jumlah desa tertinggal terbanyak yakni, Kabupaten Indragiri Hilir.

Jumlah desa dengan status desa mandiri terbanyak berada di Kabupaten Pelalawan dengan 4 desa mandiri dan jumlah kabupaten dengan 
status desa sangat tertinggal terbanyak berada di Kabupaten Kampar dengan jumlah 27 desa. Status desa tertinggal terbanyak berada di Kabupaten Indragiri Hilir dengan jumlah 116 desa. Pada Tabel 2 juga terlihat bahwa hanya Kabupaten Bengkalis dan Kabupaten Siak yang tidak memiliki desa dengan status sangat tertinggal.

\section{Anggaran Desa dan Indeks Desa Membangun Provinsi Riau}

Besaran anggaran Alokasi Dana Desa tahun 2018 yang diterima oleh desa di Provinsi Riau disesuaikan dengan kemampuan keuangan daerah. masing-masing kabupaten memiliki anggaran APBD yang berbeda menyebabkan jumlah perolehan anggaran Alokasi Dana Desa pada rentang yang cukup lebar. Perbandingan jumlah Alokasi Dana Desa dan Dana Desa per Kabupaten Di Provinsi Riau sesuai dengan Grafik dibawah ini:

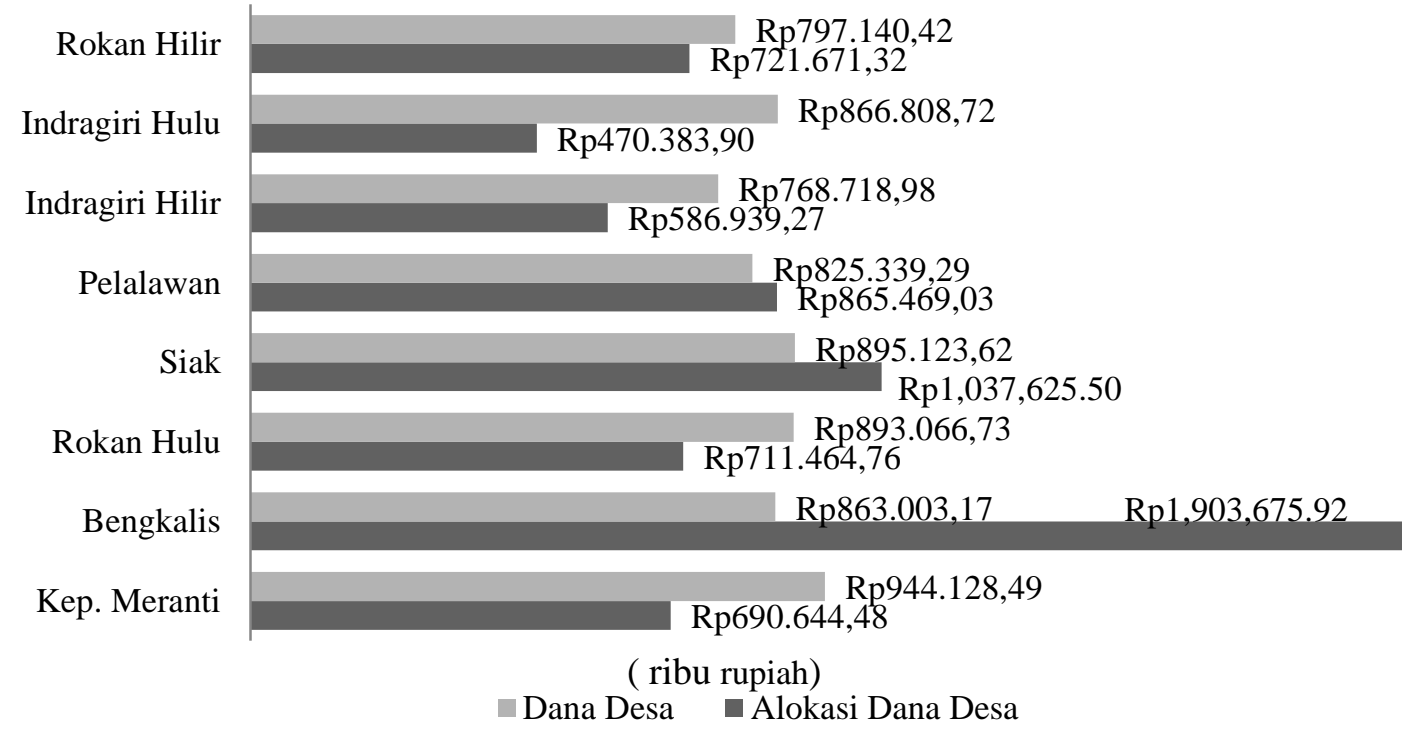

Gambar 1. Perbandingan rata-rata alokasi anggaran per Kabupaten di Provinsi Riau 2018

Sesuai dengan Gambar 1, jumlah Alokasi Dana Desa tertinggi yang disalurkan kepada desa dianggarkan oleh Kabupaten Bengkalis dengan rata-rata sebesar Rp1.903 miliar dan Kabupaten Siak dengan rata-rata sebesar Rp1.037 miliar. Kabupaten dengan penganggaran Alokasi Dana Desa terendah yang disalurkan kepada Desa adalah Kabupaten Indragiri Hulu dengan rata-rata 470.3 juta rupiah dan Kabupaten Indragiri Hilir dengan rata-rata 586.9 juta rupiah. Selisih anggaran Kabupaten Bengkalis terhadap Kabupaten Indragiri Hulu terpaut cukup jauh. Anggaran Alokasi Dana Desa Kabupaten Bengkalis 4 kali lebih besar dari rata-rata anggaran Alokasi Dana Desa Kabupaten Indragiri Hulu. Hal ini menunjukkan bahwa anggaran Alokasi Dana Desa per
Kabupaten di Provinsi Riau secara nominal tidak merata.

Dana Desa merupakan alokasi transfer pusat kepada desa juga memiliki nominal yang berbeda, perbedaan nominal tersebut didasarkan pada alokasi dasar, afirmasi dan formula. Alokasi dasar merupakan pagu sebesar 77 persen yang dibagi secara merata kepada desa. Desa dengan kategori sangat tertinggal dan tertinggal dan angka kemiskinan besar, memperoleh alokasi afirmasi 3 persen dan alokasi formula 20 persen dihitung dengan membandingkan jumlah penduduk, tingkat kemiskinan, luas desa dan kesulitan geografis.

Kabupaten dengan Dana Desa tertinggi sesuai dengan Gambar 1, adalah Kepulauan Meranti dengan rata-rata sebesar 944.1 juta rupiah dan Kabupaten terendah adalah Indragiri 
Hilir dengan rata-rata 768.7 juta rupiah. Perbedaan jumlah rata-rata Dana Desa yang diperoleh desa per Kabupaten di Provinsi Riau hanya pada rentang 22.91 persen antara kabupaten tertinggi dengan kabupaten terendah. Hal ini menunjukkan bahwa dana desa terbagi secara merata pada seluruh kabupaten di Provinsi Riau.

Perbandingan antara Kabupaten Bengkalis, Siak dan Pelalawan memiliki rata-rata Alokasi Dana Desa yang melebihi anggaran Dana Desa, dan sebanyak empat kabupaten lainya memiliki rata-rata Alokasi Dana Desa yang lebih rendah dari anggaran Dana Desa.

Pada Tabel 3, dengan menggunakan matriks untuk melihat besaran Alokasi Dana Desa terhadap Indeks Desa Membangun, desa dikategorikan dalam empat kuadran sebagai berikut:

Tabel 3. Matriks desa berdasarkan persebaran jumlah alokasi Dana Desa dan Indeks Desa Membangun

\begin{tabular}{lll}
\hline & $\begin{array}{l}\text { Alokasi Dana } \\
\text { Desa lebih } \\
\text { tinggi dari } \\
\text { rata-rata } \\
\text { Provinsi Riau }\end{array}$ & $\begin{array}{l}\text { Alokasi Dana } \\
\text { Desa lebih } \\
\text { rendah dari } \\
\text { rata-rata } \\
\text { Provinsi Riau }\end{array}$ \\
\hline $\begin{array}{l}\text { Indeks Desa } \\
\text { Membangun } \\
\text { lebih tinggi dari } \\
\text { rata-rata } \\
\text { Provinsi Riau }\end{array}$ & & \\
\hline $\begin{array}{l}\text { Indeks Desa } \\
\text { Membangun } \\
\text { lebih rendah } \\
\text { dari rata-rata }\end{array}$ & 213 & 339 \\
Provinsi Riau & & \\
\hline
\end{tabular}

Kuadran I adalah desa dengan capaian Indeks Desa Membangun 2019 yang lebih tinggi dari rata-rata indeks Provinsi Riau dan nilai Alokasi Dana Desa melebihi rata-rata Provinsi Riau dengan kata lain nilai Alokasi Dana Desa berbanding lurus dengan capaian Indeks Desa Membangun. Jumlah desa pada kuadran ini adalah sebanyak 213 desa.

Desa kuadran II adalah desa dengan capaian Indeks Desa Membangun 2019 lebih tinggi dari rata-rata indeks Provinsi Riau dan nilai Alokasi Dana Desa lebih rendah dari rata-rata Provinsi Riau. Jumlah desa pada kuadran ini adalah sebanyak 339 desa. Artinya, desa pada kuadran ini capaian Indeks Desa Membangun tidak didukung oleh Alokasi Dana Desa.

Desa kuadran III adalah desa dengan capaian Indeks Desa Membangun 2019 lebih rendah dari rata-rata indeks Provinsi Riau tetapi nilai Alokasi Dana Desa melebihi rata-rata Provinsi Riau. Jumlah desa pada kuadran ini adalah 82 desa pada kuadran ini adalah desa yang tidak mampu mengoptimalkan penggunaan Alokasi Dana Desa untuk meningkatkan capaian Indeks Desa Membangun.

Desa kuadran IV adalah desa dengan capaian Indeks Desa Membangun 2019 lebih rendah dari indeks Provinsi Riau dan nilai Alokasi Dana Desa lebih rendah dari rata-rata Provinsi Riau. jumlah desa pada kuadran ini adalah sebanyak 398 desa.

Berdasarkan matriks diatas. Jumlah desa dengan capaian Indeks Desa Membangun yang berbanding lurus pada kuadran I dan IV berjumlah sebanyak 611 desa. Sedangkan desa yang tidak terpengaruh dengan jumlah Alokasi Dana Desa yang lebih kecil tetapi menghasilkan capaian indeks lebih baik berjumlah 339 desa. Desa yang tidak mampu mengoptimalkan anggaran untuk mencapai Indeks Desa Membangun yang lebih tinggi sebanyak 83 desa. Dapat disimpulkan bahwa Alokasi Dana Desa berpengaruh signifikan terhadap Indeks Desa Membangun di Provinsi Riau.

Berikutnya penggunaan matriks untuk mengetahui sebaran Dana Desa terhadap Indeks Desa Membangun juga dilakukan dalam empat kuadran dengan hasil sebagaimana ditampilkan pada Tabel 4.

Tabel 4. Matriks desa berdasarkan persebaran jumlah Dana Desa dan Indeks Desa Membangun

\begin{tabular}{llc}
\hline & $\begin{array}{l}\text { Dana Desa lebih } \\
\text { tinggi dari rata- } \\
\text { rata Provinsi } \\
\text { Riau }\end{array}$ & $\begin{array}{l}\text { Dana Desa } \\
\text { lebih rendah } \\
\text { dari rata-rata } \\
\text { Provinsi Riau }\end{array}$ \\
\hline $\begin{array}{l}\text { Indeks Desa } \\
\text { membangun } \\
\text { lebih tinggi } \\
\text { dari rata-rata }\end{array}$ & 182 & 370 \\
Provinsi Riau & & \\
\hline $\begin{array}{l}\text { Indeks Desa } \\
\text { membangun }\end{array}$ & & 326 \\
$\begin{array}{l}\text { lebih rendah } \\
\text { dari rata-rata }\end{array}$ & 154 & \\
\hline
\end{tabular}


Provinsi Riau

Kuadran I adalah desa dengan capaian Indeks Desa Membangun 2019 lebih tinggi dari rata-rata indeks Provinsi Riau dan nilai Dana Desa melebihi rata-rata Provinsi Riau. Jumlah desa pada kuadran ini adalah sebanyak 182 desa.

Desa pada kuadran II merupakan desa dengan capaian Indeks Desa Membangun tidak didukung oleh Dana Desa. Jumlah desa pada kuadran ini adalah yang terbanyak dari desa kuadran lainnya dengan jumlah 370 desa. Desa kuadran ini memiliki capaian Indeks Desa Membangun 2019 lebih tinggi dari rata-rata indeks Provinsi Riau dan nilai Dana Desa lebih rendah rata-rata Provinsi Riau.

Desa kuadran III adalah desa dengan capaian Indeks Desa Membangun 2019 lebih rendah dari rata-rata indeks Provinsi Riau tetapi nilai Dana Desa melebihi rata-rata Provinsi Riau. Jumlah desa pada kuadran ini adalah 154 desa. Desa pada kuadran ini adalah desa yang tidak mampu mengoptimalkan penggunaan Dana Desa untuk meningkatkan capaian Indeks Desa Membangun.

Desa kuadran IV adalah desa dengan capaian Indeks Desa Membangun 2019 yang lebih rendah dari indeks Provinsi Riau dan nilai Dana Desa lebih rendah dari rata-rata Provinsi Riau. Jumlah desa pada kuadran ini adalah sebanyak 326 desa.

Berdasarkan matriks pada tabel 4 di atas, jumlah desa dengan capaian yang berbanding lurus pada kuadran I dan IV berjumlah sebanyak 408 desa. Sedangkan desa yang tidak terpengaruh dengan jumlah Dana Desa yang lebih kecil tetapi menghasilkan indeks yang lebih baik berjumlah 370 desa dan sebanyak 154 Desa tidak mampu mengoptimalkan anggaran untuk mencapai Indeks Desa Membangun. Jumlah desa yang terpengaruh dengan Dana Desa pada kuadran I dan IV berjumlah relatif sama dengan jumlah desa pada kuadran II dan III sehingga tidak dapat disimpulkan Dana Desa berpengaruh signifikan terhadap capaian Indeks Desa Membangun di Provinsi Riau.

\section{Kesulitan Geografis, Rumah Tangga Desa Dan Indeks Desa Membangun Provinsi Riau}

Indeks Kesulitan Geografis merupakan ukuran untuk menentukan tipologi desa berdasarkan tingkat kesulitan akses ke wilayah suatu desa. Indeks Kesulitan Geografis merupakan indeks yang disusun berdasarkan penilaian yang dilakukan pada setiap instrumen pendataan potensi desa yang membentuk kesulitan geografis suatu desa. Faktor yang mempengaruhi kesulitan geografis adalah pertama tersedianya pelayanan dasar meliputi pendidikan dan kesehatan, kedua keadaan infrastruktur yang meliputi sarana dan prasarana ekonomi dan energi, dan ketiga aksesibilitas jalan dan sarana transportasi. Desa dengan pelayanan dasar yang tersedia, kondisi infrastruktur yang baik dan aksesibilitas transportasi yang mudah memiliki bobot nilai Indeks Kesulitan Geografis yang mendekati 0 (nol) sebaliknya desa dengan pelayanan dasar tidak tersedia, kondisi infrastruktur buruk dan aksesibilitas transportasi yang sulit memiliki bobot nilai Indeks Kesulitan Geografis mendekati 100 (seratus). Indeks Kesulitan Geografis yang tinggi merupakan penghambat pembangunan (Adinugroho et al., 2016)

Berdasarkan Peraturan Menteri Keuangan Nomor 247/PMK.07/2015, Indeks Kesulitan Geografis Desa Di Provinsi Riau dapat dilihat pada Tabel 5.

Tabel 5. Indeks Kesulitan Geografis Desa per Kabupaten di Provinsi Riau

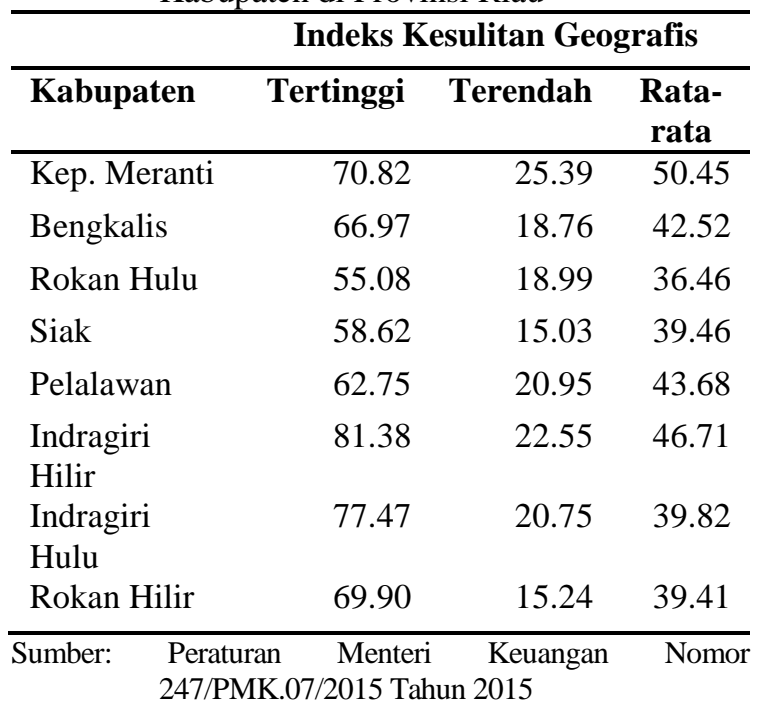


Berdasarkan Tabel 5, kabupaten dengan tingkat kesulitan geografis tertinggi rata rata berada di Kabupaten Kepulauan Meranti dengan Indeks Kesulitan Geografis 50.45, Indragiri Hilir dengan Indeks Kesulitan Geografis 46.71 dan Pelalawan 43.68. Ketiga kabupaten ini merupakan daerah yang berada di bagian Riau pesisir dan memiliki banyak pulau-pulau. Artinya pelayanan dasar, infrastruktur dan aksesibilitas sarana transportasi yang terbatas menyebabkan nilai Indeks Kesulitan Geografis ketiga kabupaten tersebut lebih tinggi daripada kabupaten yang berada di bagian Riau daratan. Sedangkan desa dengan Indeks Kesulitan Geografis tertinggi berada di Kabupaten Indragiri Hilir dengan skor Indeks Kesulitan Geografis 81.38, Kabupaten Indragiri Hulu dengan skor 77.47 dan Kabupaten Kepulauan Meranti dengan skor 70.82. Sebaliknya, Kabupaten Rokan Hulu, Kabupaten Siak dan Kabupaten Indragiri Hulu memiliki nilai skor Indeks Kesulitan Geografis yang lebih baik dari Kabupaten lainnya. Bahkan Kabupaten Siak memiliki desa dengan skor Indeks Kesulitan Geografis terendah yakni 15.03.

Pada matriks dibawah ini desa dikelompokkan untuk melihat kondisi kesulitan geografis terhadap capaian Indeks Desa Membangun menjadi empat kuadran sebagaimana ditampilkan pada Tabel 6 .

Tabel 6. Matriks persebaran desa berdasarkan Indeks Kesulitan Geografis dan Indeks Desa Membangun

\begin{tabular}{lll}
\hline & $\begin{array}{l}\text { Indeks } \\
\text { Kesulitan } \\
\text { Geografis } \\
\text { lebih rendah } \\
\text { dari rata-rata } \\
\text { Provinsi Riau }\end{array}$ & $\begin{array}{l}\text { Indeks } \\
\text { Kesulitan } \\
\text { Geografis } \\
\text { lebih tinggi } \\
\text { dari rata-rata } \\
\text { Provinsi Riau }\end{array}$ \\
\hline $\begin{array}{l}\text { Indeks Desa } \\
\text { Membangun } \\
\text { lebih tinggi dari } \\
\text { rata-rata } \\
\text { Provinsi Riau }\end{array}$ & & \\
\hline $\begin{array}{l}\text { Indeks Desa } \\
\text { Membangun } \\
\text { lebih rendah } \\
\text { dari rata-rata }\end{array}$ & 371 & \\
Provinsi Riau & & \\
\hline
\end{tabular}

Kuadran I adalah desa dengan capaian Indeks Desa Membangun 2019 lebih tinggi dari rata-rata indeks Provinsi Riau dan Indeks Kesulitan Geografis lebih rendah dari rata-rata Provinsi Riau. Jumlah desa pada kuadran ini adalah sebanyak 371 desa.

Desa kuadran II adalah desa dengan capaian Indeks Desa Membangun 2019 lebih tinggi dari rata-rata indeks Provinsi Riau dan nilai Indeks Kesulitan Geografis lebih tinggi dari rata-rata Provinsi Riau. Jumlah desa pada kuadran ini adalah sebanyak 181 desa.

Desa kuadran III adalah desa dengan capaian Indeks Desa Membangun 2019 yang lebih rendah dari rata-rata indeks Provinsi Riau tetapi nilai Indeks Kesulitan Geografis lebih rendah dari rata-rata Provinsi Riau. Jumlah desa pada kuadran ini adalah 179 desa.

Desa kuadran IV adalah desa dengan capaian Indeks Desa Membangun 2019 yang lebih rendah dari indeks Provinsi Riau dan nilai Indeks Kesulitan Geografis lebih tinggi dari ratarata Provinsi Riau. jumlah desa pada kuadran ini adalah sebanyak 301 desa.

Berdasarkan matriks diatas, Dilihat dari jumlah Desa Kuadran I dan IV yang mencapai 671 desa dapat disimpulkan ternyata Indeks Kesulitan Geografis berpengaruh signifikan terhadap capaian Indeks Desa Membangun di Provinsi Riau. Hal ini menjelaskan tingginya nilai Indeks Kesulitan Geografis merupakan faktor penghambat dalam pembangunan. Desa dengan Indeks Kesulitan geografis yang tinggi memiliki sarana prasarana yang sangat minim pada bidang pendidikan, kesehatan, transportasi dan komunikasi. Kesimpulan ini mendukung penelitian yang dikemukakan oleh (Adinugroho $e t$ al., 2016) yang menyimpulkan hubungan Indeks Kesulitan Geografis berdampak negatif terhadap Indeks Pembangunan Desa di Kabupaten Kulonprogo.

Variabel Jumlah Rumah Tangga merupakan keadaan khas sumber daya manusia yang memiliki potensi keunggulan secara kuantitatif. Dilihat dari jumlah rumah tangga sebagai potensi spesifik sumber daya manusia, sebaran rata-rata Rumah Tangga atau disebut Kepala Keluarga (KK) per desa di Provinsi Riau 
pada tahun 2018 dapat dilihat pada grafik dibawah ini:

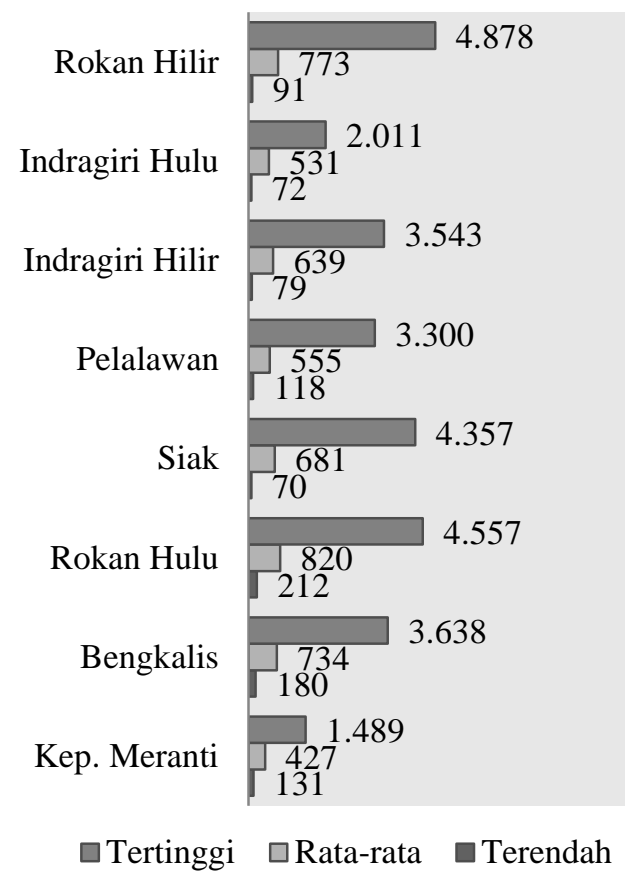

Gambar 2. Rata-rata jumlah rumah tangga desa per kabupaten di Provinsi Riau tahun 2018 (jiwa) Sumber: Potensi Desa Badan Pusat Statistik 2018.

Berdasarkan Gambar 2, rata-rata jumlah penduduk desa tertinggi berada di Kabupaten Rokan Hulu dengan 820 Kepala Keluarga (KK) dan Rokan Hilir dengan 773 KK. Sedangkan jumlah rumah tangga terendah secara rata-rata adalah Kabupaten Kepulauan Meranti dengan 427 KK dan Kabupaten Indragiri Hulu sebanyak $531 \mathrm{KK}$.

Desa dengan jumlah rumah tangga terendah berada di Kabupaten Siak sebanyak 70 KK, Indragiri Hulu, 72 KK dan Indragiri Hilir 79 KK. Sedangkan desa dengan jumlah KK tertinggi berada Kabupaten Rokan Hilir dengan 4,878 KK, Kabupaten Rokan Hulu dengan 4,557 KK dan Kabupaten Siak 4.357 KK serta Kabupaten Bengkalis 3,638 KK.

Pada matriks dibawah ini desa dikelompokkan menjadi empat kuadran untuk melihat Jumlah Rumah Tangga Desa terhadap Indeks Desa Membangun dihasilkan pengkategorian sebagaimana ditampilkan pada Tabel 7.
Tabel 7. Matriks persebaran desa berdasarkan jumlah rumah tangga desa dan Indeks Desa Membangun

\begin{tabular}{lll}
\hline & $\begin{array}{l}\text { Jumlah } \\
\text { Rumah } \\
\text { tangga Desa } \\
\text { lebih tinggi } \\
\text { dari rata-rata } \\
\text { Provinsi Riau }\end{array}$ & $\begin{array}{l}\text { Jumlah } \\
\text { Rumah } \\
\text { tangga Desa } \\
\text { lebih rendah } \\
\text { dari rata-rata } \\
\text { Provinsi Riau }\end{array}$ \\
\hline $\begin{array}{l}\text { Indeks Desa } \\
\text { Membangun } \\
\text { lebih tinggi dari } \\
\text { rata-rata n } \\
\text { Provinsi Riau }\end{array}$ & & \\
\hline $\begin{array}{l}\text { Indeks Desa } \\
\text { Membangun } \\
\text { lebih rendah } \\
\text { dari rata-rata }\end{array}$ & 251 & 301 \\
Provinsi Riau & & \\
\hline
\end{tabular}

Kuadran I adalah desa dengan capaian Indeks Desa Membangun 2019 lebih tinggi dari rata-rata indeks Provinsi Riau dan jumlah rumah tangga desa lebih tinggi dari rata-rata Provinsi Riau. Jumlah desa pada kuadran ini adalah sebanyak 251 desa.

Desa kuadran II adalah desa dengan capaian Indeks Desa Membangun 2019 lebih tinggi dari rata-rata indeks Provinsi Riau dan nilai jumlah rumah tangga Desa lebih tinggi dari ratarata Provinsi Riau. Jumlah desa pada kuadran ini adalah sebanyak 301 desa.

Desa kuadran III adalah desa dengan capaian Indeks Desa Membangun 2019 lebih rendah dari rata-rata indeks Provinsi Riau tetapi nilai jumlah rumah tangga Desa lebih tinggi dari rata-rata Provinsi Riau. jumlah desa pada kuadran ini adalah 107 Desa.

Desa kuadran IV adalah desa dengan capaian Indeks Desa Membangun 2019 lebih rendah dari Indeks Provinsi Riau dan nilai jumlah rumah tangga lebih rendah dari rata-rata Provinsi Riau. jumlah desa pada kuadran ini adalah sebanyak 373 desa.

Berdasarkan matriks pada Tabel 7, jumlah desa yang tidak terpengaruh dengan jumlah rumah tangga terhadap capaian Indeks Desa Membangun berjumlah 301 desa lebih rendah daripada jumlah desa pada kuadran I dan IV berjumlah 624 desa, ini mengindikasikan bahwa jumlah rumah tangga berdampak signifikan 
terhadap capaian Indeks Desa Membangun di Provinsi Riau.

\section{Dampak Alokasi Dana Desa, Dana Desa, Indeks Kesulitan Geografis dan Jumlah Rumah Tangga terhadap Status Desa di Provinsi Riau}

Berdasarkan hasil pengumpulan data pada penelitian ini, dengan menggunakan teknik accidental sampling, diperoleh sampel sebanyak 1032 desa untuk mewakili populasi desa di provinsi Riau. Sampel ini tersebar di 8 dari 10 Kabupaten di Provinsi Riau. Selanjutnya dilakukan penghitungan terhadap persamaan model ekonometrika menggunakan aplikasi SPSS 16.0.

Uji signifikansi simultan atau uji Anova (F) digunakan untuk mengidentifikasi apakah model yang digunakan layak atau atau tidak. Uji f atau Anova juga digunakan dalam pengujian untuk mengetahui bagaimana semua variabel independen secara bersama-sama mempengaruhi variabel dependen. Adapun hasil uji F menggunakan SPSS.16.0 menghasilkan nilai sesuai dengan Tabel 8.

\begin{tabular}{lrcc}
\multicolumn{4}{c}{ Tabel 8. Uji Simultan Anova (F) } \\
\hline \multicolumn{1}{c}{ Model } & $\begin{array}{c}\text { Sum Of } \\
\text { Square }\end{array}$ & F & Sig \\
\hline Regression & 1.158 & 78.521 & .000 \\
Residual & 3.785 & & \\
Total & 4.943 & & \\
\hline
\end{tabular}

Hasil pengujian simultan $(\mathrm{F})$ menunjukan pada tingkat signifikansi $1 \%$ nilai $F_{\text {hitung }}$ berjumlah 78.521 dengan signifikansi 0.000 dimana 0.000 lebih kecil daripada $\alpha 1 \%$. Hal ini menjelaskan bahwa berdasarkan pengujian tersebut, persamaan model regresi yang digunakan dalam penelitian ini signifikan dan layak untuk digunakan. Berdasarkan tabel tersebut, didapat hasil pengukuran yang menunjukkan bahwa variabel Alokasi Dana Desa, Dana Desa, Indeks Kesulitan Geografis dan Jumlah Rumah Tangga secara bersama-sama berpengaruh signifikan terhadap variabel Indeks Desa Membangun di Provinsi Riau. Persamaan model penelitian dilakukan pengujian secara parsial atau uji $\mathrm{t}$ untuk menganalisis apakah masing-masing variabel Alokasi Dana Desa, Dana Desa, Indeks Kesulitan Geografis dan Jumlah Rumah Tangga mempengaruhi Indeks Desa Membangun. Uji t disebut uji parsial, merupakan pengujian yang mengidentifikasi apakah setiap variabel independen mempengaruhi variabel dependen secara terpisah. Pada pengujian ini dilakukan uji signifikansi parsial (t) dengan menggunakan SPSS.16.0. Adapun hasil pengujian dapat dilihat pada Tabel 9 di bawah ini:

\begin{tabular}{lrrrr} 
Tabel 9. Uji & \multicolumn{5}{l}{ Signifikansi Parsial (t) } \\
\cline { 1 - 3 } Model & \multicolumn{2}{c}{$\begin{array}{c}\text { Unstandardized } \\
\text { Coefficients }\end{array}$} & $\mathrm{t}$ & Sig \\
& \multicolumn{1}{c}{$\mathrm{B}$} & \multicolumn{3}{c}{ Std. } \\
& \multicolumn{5}{c}{ Error } \\
\cline { 2 - 4 } Cons & .713 & .011 & 62.322 & .000 \\
$\mathbf{X 1}$ & .003 & .000 & 6.198 & .000 \\
$\mathbf{X 2}$ & -.003 & .001 & -3.066 & .002 \\
$\mathbf{X 3}$ & -.021 & .002 & -11.336 & .000 \\
$\mathbf{X 4}$ & 002 & .000 & 4.874 & .000 \\
\hline
\end{tabular}

Berdasarkan Tabel 9 hasil uji parsial masing masing variabel pada taraf signifikansi $\alpha$ $1 \%$ menunjukkan semua variabel secara parsial berpengaruh signifikan terhadap variabel Indeks Desa Membangun. Variabel Alokasi Dana Desa (X1) memiliki nilai koefisien 0.003 dengan nilai $\mathrm{t}_{\text {hitung }} 6.198$ dan signifikansi 0.000 yang lebih kecil dari $\alpha 1 \%$. Koefisien variabel Alokasi Dana Desa yang positif mengindikasikan bahwa kenaikan anggaran Alokasi Dana Desa berpengaruh positif terhadap Kenaikan Indeks Desa Membangun. Setiap tambahan Rp 100,000,000.00 (seratus juta rupiah ) anggaran Alokasi Dana Desa akan meningkatkan nilai Indeks Desa Membangun sebanyak 0.003 .

Variabel Dana Desa (X2) -0.003 dengan $\mathrm{t}_{\text {hitung }}-3.066$ dan signifikansi 0.002 yang lebih kecil dari $\alpha 1 \%$. Koefisien variabel Dana Desa yang negatif mengindikasikan bahwa kenaikan anggaran Dana Desa berpengaruh negatif terhadap kenaikan Indeks Desa Membangun. setiap tambahan Rp 100,000,000.00 (seratus juta rupiah ) anggaran Dana Desa akan mengurangi nilai Indeks Desa Membangun sebanyak 0.003.

Variabel Indeks Kesulitan Geografis (X3) dengan nilai koefisien -0.021 dengan nilai $t_{\text {hitung }}$ 11.336 dan signifikansi 0.000 yang lebih kecil 
dari $\alpha 1 \%$. Koefisien variabel yang negatif mengindikasikan Indeks Kesulitan Geografis yang semakin tinggi akan berpengaruh menurunkan nilai Indeks Desa Membangun . Artinya desa dengan tingkat kesulitan geografis yang tinggi menyebabkan Indeks Desa Membangun menjadi rendah. Sedangkan desa dengan Indeks Kesulitan Geografis yang nilainya rendah menyebabkan nilai Indeks Desa Membangun menjadi tinggi. Setiap kenaikan 10 poin indeks Kesulitan Geografis akan menurunkan Indeks Desa Membangun sebesar 0.021

Terakhir variabel Jumlah Rumah Tangga (X4) dengan nilai koefisien 0.002 dengan $t_{\text {hitung }}$ 4.874 dan signifikansi 0.000 yang lebih kecil dari $\alpha 1 \%$. Koefisien variabel rumah tangga yang positif mengindikasikan bahwa setiap kenaikan tambahan jumlah rumah tangga akan berpengaruh positif terhadap kenaikan Indeks Desa Membangun. Tambahan 100 (seratus) jumlah rumah tangga akan meningkatkan Indeks Desa Membangun sebesar 0.002 .

Berdasarkan hasil uji signifikansi simultan (F) dan uji signifikansi parsial (t) terhadap masing-masing variabel menunjukkan tingkat signifikansi yang lebih kecil dari taraf signifikansi $\alpha 1 \%$. Oleh karena itu, diperoleh kesimpulan bahwa variabel Alokasi Dana Desa, Dana Desa, Indeks Kesulitan Geografis dan Jumlah Rumah Tangga secara simultan mempengaruhi variabel Indeks Desa Membangun. Sesuai dengan hipotesis penelitian $\mathrm{H}_{1}$ Terdapat pengaruh signifikan Alokasi Dana Desa, Dana Desa, Indeks Kesulitan Geografis dan Jumlah Rumah Tangga terhadap nilai Indeks Desa Membangun diterima dan $\mathrm{H}_{0}$ ditolak.

Berdasarkan hasil uji statistik menggunakan regresi linear berganda tersebut di atas, didapat persamaan model penelitian sebagai berikut:

\section{$\mathrm{Y}=0,713+0.003 X 1-0.003 X 2-0.021 X 3+0.002 X 4+e$}

Kelayakan model penelitian perlu dilakukan setelah hipotesis diterima. Uji determinasi $\left(\mathrm{R}^{2}\right)$ dilakukan untuk menganalisis seberapa persen model penelitian ini mampu menjelaskan dampak variabel Alokasi Dana Desa, Dana Desa, Indeks Kesulitan Geografis dan Jumlah Rumah Tangga terhadap nilai Indeks Desa Membangun secara keseluruhan. Berdasarkan hasil uji determinasi $\left(\mathrm{R}^{2}\right)$ diperoleh hasil $\mathrm{R}^{2}$ sebesar 23.4 persen dan adjusted $\mathrm{R}^{2} 23.1$ persen. Hasil ini mengindikasikan bahwa kemampuan variabel bebas Alokasi Dana Desa, Dana Desa, Indeks Kesulitan Geografis dan Jumlah Rumah Tangga mampu menjelaskan variabel Indeks Desa Membangun sebesar 23.1 persen. variabel lain yang tidak dijelaskan dan diteliti dalam penelitian ini sebanyak 76.9 persen.

\section{KESIMPULAN DAN REKOMENDASI}

Indeks Desa Membangun Provinsi Riau tahun 2019 memiliki nilai rata-rata 0.626. sebanyak 3 kabupaten berada dibawah rata-rata provinsi yakni, Kabupaten Kuantan Sengingi 0.609, Kabupaten Kepulauan Meranti 0.600 dan Kabupaten Indargiri Hilir skor 0.582. Indeks Desa Membangun Provinsi Riau pada tahun 2019 menunjukkan bahwa masih terdapat $45(2.8 \%)$ desa sangat tertinggal, $422(26.5 \%)$ desa tertinggal.

Pendapatan desa di Provinsi Riau tahun 2018 dari kelompok Alokasi Dana Desa memiliki rata-rata sebesar $\mathrm{Rp} 848,776,382.00$ dan Dana Desa sebesar Rp 848,249,348.00. Berdasarkan hasil pengelompokkan matriks capaian Indeks Desa Membangun menghasilkan kesimpulan bahwa tinggi rendahnya Alokasi Dana Desa berbanding lurus terhadap kenaikan dan penurunan Indeks Desa Membangun. sebaliknya Dana Desa tidak memiliki dampak yang signifikan terhadap kenaikan dan penurunan Indeks Desa Membangun.

Pengelompokkan matriks kondisi kesulitan geografis dan rumah tangga terhadap Indeks Desa Membangun menunjukkan masing-masing variabel berpengaruh signifikan terhadap kenaikan dan penurunan Indeks Desa Membangun.

Hasil pengujian secara regresi menemukan bahwa dampak Alokasi Dana Desa, Dana Desa, Indeks Kesulitan Geografis dan Jumlah Rumah Tangga secara bersama 
berdampak signifikan terhadap Indeks Desa Membangun yang mengkategorikan Status desa di Provinsi Riau. Dimana Alokasi Dana Desa dan Jumlah Rumah Tangga berpengaruh positif terhadap kenaikan Indeks Desa Membangun sedangkan Dana Desa dan Indeks Kesulitan Geografis berpengaruh negatif terhadap kenaikan Indeks Desa Membangun. Hasil uji determinasi menunjukkan bahwa variabel penelitian hanya mampu menjelaskan sebesar $23.1 \%$ dari capaian Indeks Desa Membangun Provinsi Riau tahun 2019.

Peningkatan Indeks Desa Membangun dengan tujuan kenaikan status desa dapat dilakukan dengan lebih meningkatkan anggaran Alokasi Dana Desa. Kenaikan anggaran harus diikuti perencanaan yang matang dan pertimbangan skala prioritas. Pemerintah desa perlu memprioritaskan pada pemenuhan aspek yang menjadi indikator penilaian Indeks Desa Membangun yang masih terkategori rendah.

Tata kelola penggunaan Dana Desa perlu disertai pendampingan oleh pemerintah yang dimulai sejak tahapan perencanaan, penganggaran, pelaksanaan, pelaporan dan evaluasi. Pendampingan dilakukan dengan cara pembinaan, peningkatan kualitas sumber daya manusia, partisipasi masyarakat dan pemahaman regulasi bagi pengguna anggaran. selanjutnya sasaran pemanfaatan Dana Desa perlu mengacu kepada prioritas penggunaan Dana Desa sesuai dengan hasil rekomendasi Indeks Desa Membangun. Belanja desa melalui anggaran Dana Desa tidak hanya difokuskan kepada belanja bidang pembangunan akan tetapi perlu digunakan pada bidang pemberdayaan masyarakat dan pembinaan kemasyarakatan sesuai dengan kebutuhan yang tercantum dalam dokumen perencanaan dengan disertai inovasi memajukan pembangunan desa.

Peran serta pemerintah daerah pada sektor-sektor yang tidak dapat dilaksanakan oleh pemerintah desa. Sektor pendidikan, kesehatan, energi serta transportasi merupakan sektor pembangunan yang tidak dapat sepenuhnya dibiayai oleh pemerintah desa. Kewenangan fungsi urusan pemerintahan tersebut berada di pemerintah daerah. Sudah seharusnya pemerintah daerah memetakan dan memprioritaskan desa dengan Indeks Kesulitan Geografis yang tinggi sebagai prioritas pembangunan secara sektoral. Indeks Kesulitan Geografis yang tinggi menghambat pembangunan dan menurunkan kemampuan untuk meningkatkan Indeks Desa Membangun.

Pengentasan desa sangat tertinggal dan tertinggal perlu menjadi fokus utama. Sasaran pengentasan dilakukan dengan menuntaskan pemenuhan indikator variabel Indeks Desa Membangun yang diukur terkategori rendah. Pemenuhan indikator tersebut tidak hanya menjadi tanggung jawab pemerintah desa akan tetapi juga menjadi tanggung jawab pemerintah kabupaten, provinsi dan pusat, sesuai dengan kewenangan urusan pemerintah. Pemerintah daerah dan pemerintah pusat juga dapat mengalokasikan bantuan keuangan kepada desa dalam bentuk program dan kegiatan prioritas dengan rujukan rekomendasi Indeks Desa Membangun.

Penelitian ini memiliki keterbatasan baik dari sisi generalisasi dan penentuan objek kajian, metode penelitian, dan ruang lingkup variabel yang digunakan. Namun, hasil empiris ini tentunya sangat relevan dalam merepresentasikan realita Alokasi Dana Desa, Dana Desa dan kesulitan geografis dan rumah tangga terhadap status desa di Provinsi Riau. Akan tetapi, untuk kajian selanjutnya perlunya menambah eksistensi berbagai variabel yang relevan dan lebih kontributif dalam penelitian terhadap status desa yang dapat mengeksplorasi lebih jauh bagaimana meningkatkan status desa menuju kemandirian dan kesejahteraan bagi masyarakat. Kegiatan pembangunan desa membutuhkan.

\section{DAFTAR PUSTAKA}

Adinugroho, G., Arifahilah, I., Elvina, S., Inriyatni, S., \& Aisyah, T. (2016). Pola Spasial Indeks Kesulitan Geografis dan Pengaruhnya Terhadap Pembangunan Kabupaten Gunungkidul. Plano Madani,5 (2),158-170 
Arifa, I. N. (2019). Community Participation and Government Role in Using Village Funds in Dlingo Village. Policy \& Governance Review, 3(2), 171. https://doi.org/10.30589/pgr.v3i2.129

Atmojo, M. E., Fridayani, H. D., Kasiwi, A. N., \& Pratama, M. A. (2017). Efektivitas Dana Desa untuk Pengembangan Potensi Ekonomi Berbasis Partisipasi Masyarakat di Desa Bangunjiwo. ARISTA 5 (1), 126-140

Aziz, N. L. L. (2016). Otonomi Desa dan Efektivitas Dana Desa. Jurnal Penelitian Politik,3(2),93211. https://doi.org/10.14203/JPP.V13I2.575

Daraba, D. (2017). Pengaruh Program Dana Desa Terhadap Tingkat Partisipasi Masyarakat Di Kecamatan Galesong Utara Kabupaten Takalar. Sosiohumaniora, 19(1), 52-58. https://doi.org/10.24198/sosiohumaniora.v19i 1.11524

Gani, A. O. A., Gani, A., \& Arief, M. (2020). Dampak Penggunaan Dana Desa Terhadap Indikator Ketahanan Sosial, Ekonomi dan Ekologi Desa Tertinggal Kecamatan Bulukumpa Kabupaten Bulukumba. Jurnal Ilmu Ekonomi, 3(1), 78-88.

Hanibal, H. (2015). Indeks Desa Membangun Kementerian Desa, Pembangunan Daerah Tertinggal dan Transmigrasi, Jakarta Selatan

Joetarto, B., Setiawan, A., \& Farida. (2020). The Impact of Village Fund Program on Improving Well-being. JEJAK: Jurnal Ekonomi Dan Kebijakan, 13(2), 343-364.

Karmawan, Akbar, M. F., Yunita, A., Christianungrum, \& Yanuar, D. (2020). Contribution of Village Fund to Development and Social Empowerment and Coastal Community Economy in the Village of West Kurau and Village of Kurau in Central Bangka Regency. Journal of Talent Development and Excellence, Vol (12) No.3s, 1602-1610.

Kuncoro, M. (2019). Ekonomika Desa. Yogyakarta, UPP STIM YKPN

Lalira, D., Nakoko, A. T., \& Rorong, I. P. (2018). Pengaruh Dana Desa dan Alokasi Danan Desa Terhadap Tingkat Kemiskinan di Kecamatan Gemeh Kabupaten Kepulauan Talaud. Jurnal Berkala Ilmiah efisiensi, 18(4)

Lewis, D. \& Blane. (2015) Decentralising to Village in Indonesia: Money (and other) Mistakes. Public Administration and development, Vol 35(2), 347-359.
Menkhof, L. \& Rungruxsirivorn, O. (2011). Do Village Funds Improve Access to Finance? Evidence from Thailand. World Development, 39 (1), 110 - 122.

Muhtarom, Kusuma, N., \& Purwanti, E. (2018). Village Index Analysis Building to Know The Village Development In Gadingrejo District of Pringsewu District. Inovasi Pembangunan: Jurnal Kelitbangan, 6(02), 179-190.

https://doi.org/10.35450/jip.v6i02.96

Oktaviana, O. \& Bachrudin. (2017). Upaya Peningkatan Indeks Desa Membangun (IDM) di Wilayah Provinsi Banten Melalui Intervensi Kebijakan Pemerintah Provinsi. $L A B$-AP FISIP Untirta

Peraturan Menteri Desa Pembangunan Daerah Tertinggal Dan Transmigrasi Nomor 2 tahun 2016 Tentang Indeks Desa Membangun

Peraturan Menteri Keuangan Nomor 247/PMK.07/2015 tentang Tata Cara Pengalokasian, Penyaluran, Penggunaan, Pemantauan dan Evaluasi Dana Desa

Pratomo, A. W. (2018). Industrialisasi Melalui Dana Desa. Bunga Rampai Rekomendasi Forum Ekonom Tahun 2018.Jakarta. Kementerian Keuangan

Putra, C. K., Pratiwi, R. N., \& Suwondo. (2013). Pengelolaan Alokasi Dana Desa dalam Pemberdayaan Masyarakat Desa (Studi pada Desa Wonorejo Kecamatan Singosari Kabupaten Malang). Jurnal Administrasi Publik (JAP),1(6), 1203-1212.

Riyanto, J. 2017. Implikasi Penggunaan Dana Desa Terhadap Ketahanan Sosial, Ekonomi dan Ekologi Desa tertinggal di Kabupaten Karanganyar. Jurnal Saintech Politeknik Indonusa Surakarta

Sunu, M. K. \& Utama, M. S. (2019). Pengaruh Dana Desa Terhadap Tingkat Kemiskinan Dan Kesejahteraan Masyarakat Di Kabupaten/Kota Provinsi Bali. E-Jurnal Ekonomi Dan Bisnis Universitas Udayana, 843-872 https://doi.org/10.24843/eeb.2019.v08.i08.p0 2

Soekartawi. 1990. Teori Ekonomi Produksi (Teori dan Aplikasi). Raja Grafindo. Persada. Jakarta

Sofianto, A. (2017). Kontribusi Dana Desa terhadap Pembangunan dan Pemberdayaan Masyarakat di Kebumen dan Pekalongan. Matra Pembaruan, 1(1), 23-32. 
Journal of Regional and Rural Development Planning (Jurnal Perencanaan Pembangunan Wilayah dan Perdesaan) Oktober 2021, 5 (3): 187-202

Sugiyono. (2017). Metode Penelitian Pendidikan Pendekatan Kuantitatif, Kualitatif, dan R\&D. Bandung, Alfabeta

Tangkumahat, F. V., Panelewen, V. V. J., \& Mirah, A. D. P. (2017). Dampak Program Dana Desa Terhadap Peningkatan Pembangunan Dan Ekonomi Di Kecamatan Pineleng Kabupaten Minahasa. Agri-Sosioekonomi, 13(2A), 335. https://doi.org/10.35791/agrsosek.13.2a.2017. 17130

Undang-Undang Nomor 6 Tahun 2014 Tentang Desa

Yulitasari, Y. \& Tyas, W. P. (2020). Dana Desa dan Status Desa di Provinsi Jawa Tengah. Journal of Regional and Rural Development Planning,4(2),74-83.

https://doi.org/10.29244/jp2wd.2020.4.2.7483 